\title{
Kas-iskelet sistemi enfeksiyonlarında klinik bulgular ve radyoloji
}

\section{Diagnostic radiological modalities and clinic presentations of musculoskeletal infections}

\author{
Şafak Şahlan¹, Tuluhan Yunus Emre², İsmail Burak Atalay³, Mehmet Fatih Ekşioğlu³ , Bedii Şafak Güngör \\ 1 İntermed Kliniği, Nişantaşı, İstanbul \\ ${ }^{2}$ İstanbul Biruni Üniversitesi Tıp Fakültesi, Ortopedi ve Travmatoloji Bölümü, İstanbul \\ ${ }^{3}$ Ankara Abdurrahman Yurtaslan Onkoloji Eğitim ve Araştırma Hastanesi, Ortopedi ve Travmatoloji Kliniği, Ankara
}

\begin{abstract}
Kas-iskelet sistemi enfeksiyonlarının diğer vücut bölgelerindeki enfeksiyonlara göre anatomik ve patofizyolojik farklılıkları nedeniyle tedavileri kimi zaman güç olmakta ve tedavi başarısı kısmen daha düşük olmaktadır. Erken evrede tanısal güçlügüunden dolayı yönetimi zor tablolardır. En sık karşılaşılan patojen Staphylococcus aureus'dur. Kas-iskelet sisteminde sık karşılaşılan gram (+), gram (-) enfeksiyonlarının haricinde, tüberküloz ve tüberküloz dışı mikobakteriyel enfeksiyonlar, bruselloz, tifo ve sifiliz gibi bakteriyel enfeksiyonlar ile koksidioidomikoz, blastomikoz, histoplazmoz gibi fungal enfeksiyonlar da, nadir de olsa, karşımıza çıkabilmektedir. Erken tanı, tedavide kür ve komplikasyonları azaltmada etkilidir. Hastanın klinik prognozunda; etken patojen, hastaya bağlı özellikler ve enfeksiyon kaynağı önemli rol oynar. Yaş, immunosupresyon varlığı, eşlik eden hastalıklar (diyabet, romatoid artrit, hipoksi vb.), implant ve yabancı cisim varlığı, enfekte dokunun kan akımı ve beslenmesi hastaya bağlı özellikler olarak olarak sayılabilir. Tanıda ise düz radyografiler genellikle erken evrede tanı koyduracak hassasiyet ve özgüllüğe sahip olmamalarından dolayı tanı koymada yetersiz kalabilmektedir. Bilgisayarlı tomografi, kemiksel anatomiyi daha ayrıntılı sergileme özelliğine sahip olsa da ideal duyarlılık ve özgüllükten yoksundur. Kemik ve yumuşak doku enfeksiyonlarında manyetik rezonans görüntüleme en hassas yöntem olarak kabul edilmekte ve kapsamlı anatomik ayrıntı sağlaması ve iyonize radyasyon içermemesi nedeniyle tercih edilen ileri görüntüleme yöntemidir. Radyonükleer çalışmalar ise erken evre enfeksiyonların tanısında tercih edilmektedir. Enfeksiyonun kaynağı hematojen yayılım, penetran travma, açık kırıklar, hayvan ya da insan ısırıkları, inhalasyon veya cerrahi kontaminasyon yoluyla olabilir. Prognoz ve uygun tedavinin belirlenmesinde bu faktörler göz önünde bulundurulmalıdır. Bu bölümde kas-iskelet sistemi enfeksiyonlarının klinik ve radyolojik bulgularından bahsedeceğiz.
\end{abstract}

Anahtar sözcükler: enfeksiyon; kas-iskelet sistemi; klinik bulgu; radyoloji

\begin{abstract}
Musculoskeletal infections are diagnostic challenge because they are difficult to recognize in the early stages of the disease. Patients' initial evaluation includes history and physical examination, laboratory studies and radiological examinations. Earlier diagnosis and treatment help to reduce complications. The most common pathogen is Staphylococcus aureus. Other than gram negative and positive microorganisms, tuberculous or nontuberculous mycobacterial infections, brucellosis, typhus and syphilis, coccidioidomycosis, blastomycosis, histoplasmosis may be encountered. Due to the improvements in diagnosis methods, these infections have gradually been increasing. In the clinical prognosis of the patient, pathogen, patient characteristics, and infection source all play an important role. Age, immunosuppression, accompanying diseases (diabetes, rheumatoid arthritis, hypoxia etc.), presence of implant and foreign material, the blood supply and nutrition of the infected tissue may be counted as patient characteristics. Plain radiographs generally lack sensitivity and specificity at an early stage and usually not diagnostic. Computed tomography offers detailed bone anatomy however, lacks ideal sensitivity and specificity. Magnetic resonance imaging is considered the most sensitive modality, provides large anatomic detail, does not use ionizing radiation and has become the advanced imaging modality of choice in bone and soft tissue infections. Radionuclide modalities are also give valuable information for diagnosis. The source of the infection could be penetrative trauma, open fractures, animal or human bites or by means of inhalation, hematogenous dissemination and surgical contamination. These factors must be considered in determining the convenient treatment and the prognosis. In this chapter, clinical and radiological findings of infections of musculoskeletal system are going to be mentioned.
\end{abstract}

Key words: infection; musculoskeletal system; clinical findings; radiology

- İletişim adresi: Prof. Dr. Şafak Şahlan, Teşvikiye Cad. Bayer Apt. No:63, 34365 Nişantaşı, İstanbul

Tel: 0532 - 2765776 e-posta: ssahlan@yahoo.com

- Geliștarihi: 24 Haziran 2020 Kabul tarihi: 15 Temmuz 2020 
K as-iskelet sistemi enfeksiyonlarının diğer vücut bölgelerindeki enfeksiyonlara göre anatomik ve patofizyolojik farklılıkları nedeniyle tedavileri kimi zaman güç olmakta ve tedavi başarısı kısmen daha düşük olmaktadır. Hastaların birden fazla ameliyat geçirmeleri ve uzun süreli antibiyotik tedavisi almaları gerekebilmektedir. ${ }^{[1]}$ Enfeksiyonların oluşumunun, tipinin, ciddiyetinin ve klinik prognozunun belirlenmesinde temel olarak üç etmen rol oynar; etken patojen, hastanın özellikleri ve enfeksiyonun kaynağı. ${ }^{[2]}$ Musküloskeletal enfeksiyonların klinik tanısı bazen oldukça zordur ve görüntüleme yöntemleri tanıda önemli bir değer taşımaktadır. Tanı aşamasında görüntüleme yöntemlerinin çeşitliliği söz konusu olsa da her durum ve her hasta için optimal tek bir test mevcut değildir. Hastanın özelinde bireyselleştirilmiş yaklaşımlar tercih edilmektedir. ${ }^{[3]}$

\section{MORFOLOJIK GÖRÜNTÜLEME YÖNTEMLERI}

\section{Radyografi}

Görece ucuz ve kolay uygulanabilen bir yöntem olan direkt radyografiler kas-iskelet sistemi enfeksiyon şüphesi bulunan her hasta için başlangıçta ilk görüntüleme yöntemi olarak tercih edilmelidir. Osteomiyelitte yumuşak doku şişliği ve komşu yağlı planlarda silinme erken dönem radyolojik bulgu olarak karşımıza çıkmaktadır. Enfeksiyonun başlangıcından itibaren 10. günde medüller trabeküler lizis, fokal korteks kaybı ve periostal reaksiyon görülebilmektedir. ${ }^{[4]}$

Direkt radyografinin duyarlılığı \%43-75 ve özgüllüğü ise \%75-83 olarak değişmektedir. Pozitif bulguların varlığında tanıda oldukça yardımcı bir yöntemken bulgunun rastlanmaması enfeksiyonu dışlayamamaktadır. Direkt radyografiler tanısal olarak ek bilgi vermese bile ilgili bölgenin anatomik olarak gözden geçirilmesi ve eşlik edebilecek patolojilerin saptanması açısından önemlidir.

\section{Manyetik Rezonans Görüntüleme}

İyonize radyasyon içermemesi, kemik ve komşu yumuşak dokular hakkında ayrıntılı bulgu elde edilmesi ve hızı ulaşılabilen bir yöntem olması manyetik rezonans (MR) görüntülemenin önemli avantajları olarak sayılmaktadır. Reaktif enflamasyon ile enfeksiyonu ayırt etmedeki yetersizliği, özellikle eklem protezlerinin oluşturduğu metalik artefaktların görüntülemede yarattığı güçlükler dezavantajlarıdır.

Akut osteomiyelitlerde enfeksiyonun başlamasından sonraki ilk iki günde kemik iliğinde normalin dışında sinyal değişiklikleri gözlenmektedir.
Akut enflamasyonun bir özelliği olan enflamatuvar ödemde T1 sekanslarda hipointens, T2 yağ baskılı kesitlerde ise eksüdaya bağlı gelişen serbest sıvıyı gösteren hiperintens değişiklikler gözlenmektedir. Direkt radyografilerde gözlenmeyen periostal reaksiyon ve yumuşak doku ödemi MR görüntülerde saptanabilmektedir. Komplike olmayan durumlarda kontrast verilmesi için çok az gereksinim duyulmaktadır, çünkü kontrast sonrası T1 sekansta saptanan bulgular T2 yağ baskılı kesitlerde de gözlenmektedir. Intravenöz gadolinium ile yumuşak doku abseleri ve sinovyal kalınlaşmalar en iyi şekilde ayırt edilmektedir. ${ }^{[5]}$ MR osteomiyeliti dışlamak için \%100 negatif prediktif değere sahiptir; kemik iliği tüm sekanslarda dizilerinde tamamen normalse, enfeksiyon güvenilir bir şekilde dışlanabilir. Bununla birlikte MR'nin pozitif prediktif değeri ise kemik iliği ödeminin diğer durumlardan ayırt edilmesi açısından zayıf olması nedeni ile düşüktür.

\section{Bilgisayarlı Tomografi ve Ultrasonografi}

Bilgisayarlı tomografi (BT) ve ultrasonografi (US) akut osteomiyeliti değerlendirmede kullanılmakla birlikte ilk tercih edilen yöntemlerden değildir. Akut osteomiyelitin BT bulguları; normal medüller kanalın kemik dansitesinde artma, yağlı planlarda silinme, periost reaksiyonu ve korteks kaybı gözlenmesidir. BT ile değişiklikler direkt radyografiye göre daha erken gözlenebilse de iyonize radyasyon kullanımı ve yumuşak doku ile ilgili MR'ye göre daha az bilgi vermesi nedeniyle yaygın olarak tercih edilmemektedir.

Dünyanın birçok yerinde radyografi sonrası en fazla bulunan ekipman US'dir ve birçok yerde MR'den daha kolay ulaşımaktadır. Sonografik olarak akut osteomiyelit mutlaka subperiostal absenin varlığı ile karakterizedir. US'nin hızlı ulaşılabilir olması, küçük çocuklarda sedasyona ihtiyaç duyulmaması ve iyonize radyasyon içermemesi avantajlarıdır. Bunun yanında özellikle MR'nin kontrendike olduğu durumlarda, enstrümantasyon uygulanmış alanlarda MR ve BT'nin efektif görüntü kalitesini sağlayamadığı durumlarda oldukça kullanışlı bir yöntemdir. Kullanıcının tecrübesine bağlı olması ve yalancı pozitiflik ve yalancı negatiflik oranlarının yüksek olması ise dezavantajlarıdır. Ses dalgaları kemiğin periostunu geçemediğinden henüz subperiostal abse gelişimi yoksa erken osteomiyelit ultrasonografi ile anlaşılmayabilir. Doppler US ile periostal absenin çevresindeki hiperemi saptanabilmektedir. ${ }^{[6]}$ Tersine kemiğe komşu alanda gelişen yumuşak doku abseleri osteomiyelit ile karışabilmektedir. El bileği ve ayak gibi kompleks anatomik bölgelerin US ile değerlendirilmelerinde güçlükler bulunmaktadır. 

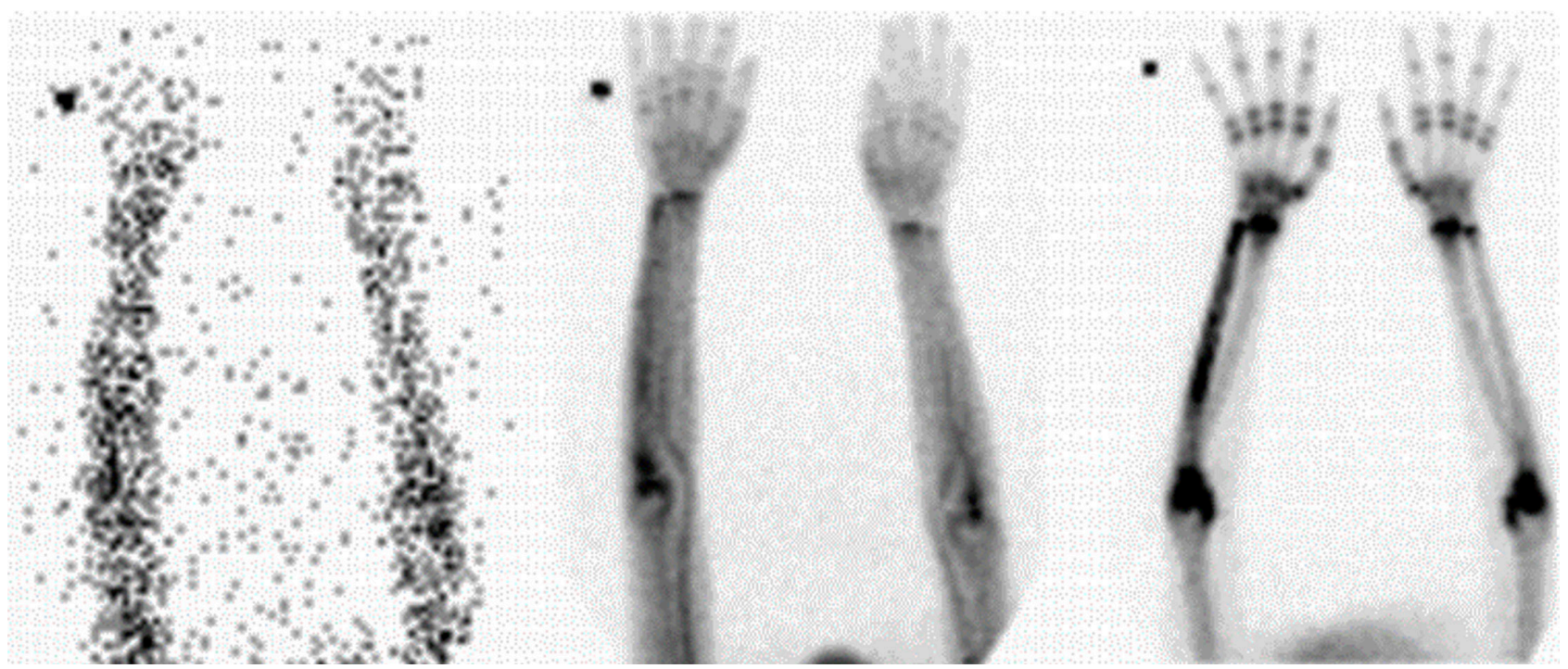

Şekil 1. Ulnanın teknesyum $99 \mathrm{~m}$-işaretli üç fazlı kemik sintigrafisi bulgusu gözlenmektedir. ${ }^{[8]}$

\section{FONKSIYONEL (RADYONÜKLEER) GÖRÜNTÜLEME YÖNTEMLERI}

\section{Üç Fazlı Kemik Sintigrafisi}

Kemik sintigrafisi teknesyum 99 m-işaretli difosfonat (genellikle metilen difosfonat) kullanılarak yapılmaktadır. Radyoaktif maddenin tutulumu kan akımına ve yeni kemik formasyon oranına göre değişim göstermektedir. Osteomiyelitten şüphe edildiğinde üç fazlı kemik sintigrafisi istenmelidir. Kemik taraması, radyoaktif maddenin enjeksiyonundan hemen sonraki dönem perfüzyon fazı, ilgili bölgeden görüntünün elde edildiği yumuşak doku fazı ve uygulamanın 2. -3 . saatinde elde edilen görüntülerin içerdiği kemik fazı olmak üzere üç fazdan oluşmaktadır. Osteomiyelitin kemik fazında saptanan klasik bulgusu, hiperperfüzyon, fokal hiperemi, fokal kemik tutulumunu içermektedir. Kemik sintigrafisi kolay ulaşılan, nispeten ucuz ve hızlı bir yöntem olarak kabul edilmektedir. Bu yöntem oldukça duyarlı bir yöntem olarak karşımıza çıkmaktadır. Semptomların ortaya çıkmasından sonraki 2-3 gün içinde bulgu vermektedir. Üç fazlı kemik sintigrafisi, \%90'dan fazla bir doğrulukla, altta yatan koşullardan etkilenmeyen osteomiyelit teşhisi için tercih edilen nükleer tıp testidir. ${ }^{[7]}$ Bununla birlikte tüm anomaliler genel olarak yeni kemik formasyon oranı ile bulgu verdiğinden, kırıklar, nöropatik eklem patolojilerinde pozitif bulgular saptandığından kemik sintigrafisinin özgüllüğünü azaltmaktadır ve bu da kemik sintigrafisini daha az kullanışlı kılmaktadır (Şekil 1). ${ }^{[8]}$

\section{Gallium Sintigrafi}

Enfeksiyon ve enflamasyonun bulunduğu pek çok durumda bu maddenin tutulumunu etkileyen durumlar karşımıza çıkmaktadır. Dolaşımda bulunan galliumun \%90'ı plasmada yer alır ve neredeyse tamamı transferrine bağlı olarak bulunur. Kan akımının ve vasküler membran geçirgenliğinin artması enflamatuvar odakta daha fazla transferrine bağlı galliumun kümelenmesi ile sonuçlanır. Gallium aynı zamanda enfeksiyonlarda yüksek konsantrasyonlarda bulunan laktoferrine de bağlanabilme özelliğine sahiptir. İn vitro çalışmalarda ise bazı bakterilere doğrudan bağlanabildiği gösterilmiştir. Bakteriler tarafından üretilen düşük molekül ağırıklı şelat olarak adlandırılan sideroforların da galliuma yüksek afiniteleri bulunmaktadır. Galliumlu sideforlar bakteriye transporte olur ve öyle ki bakteriyi fagosite eden makrofajlarda bile bu kompleks tespit edilebilmektedir. Bir miktar gallium lökositlerde de tespit edilebilmektedir (Şekil 2).

Gallium ile görüntüleme sıklıkla enjeksiyondan sonraki 18-72 saatte yapılmakta ve sıklıkla kemik sintigrafisi ile birleştirilmektedir. Açıkça pozitif ve negatif prediktifliğine güvenilse de bu yöntemin doğruluk oranı $\% 60-80$ arasında değişmektedir. ${ }^{[9]}$

\section{In Vitro Lökosit İşaretli Sintigrafi}

Enfeksiyonun radyonükleid teknikler ile görüntülenmesinde lökosit işaretlemesi bir dönüm noktası olmuştur. Birçok yöntem kullanılsa da en sık kullanılanlar lipofilik bileşen olan indium-111 oksikinolon ve 


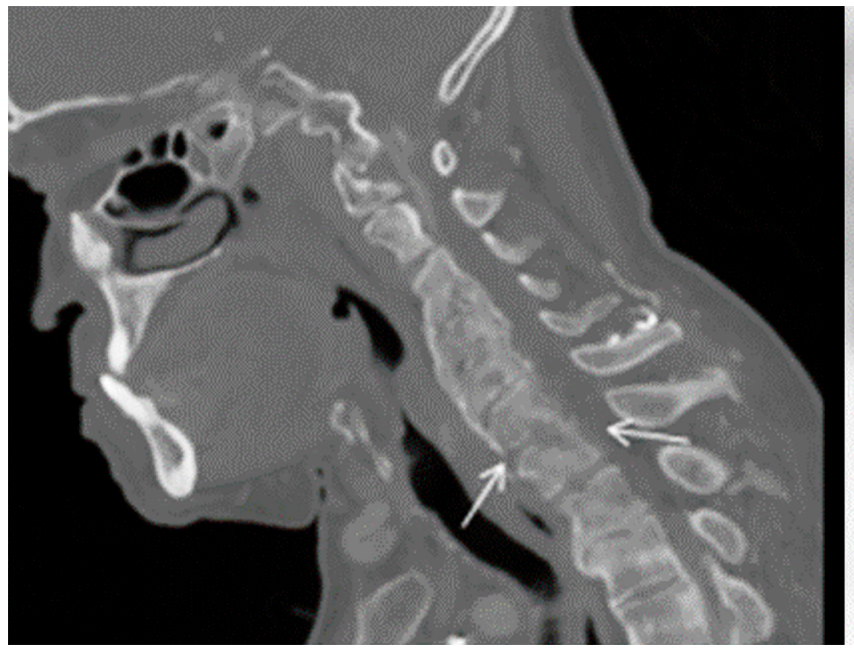

Şekil 2. Servikal omurga osteomiyelit vakasına ait Gallium ${ }^{67}$ sintigrafi bulguları.
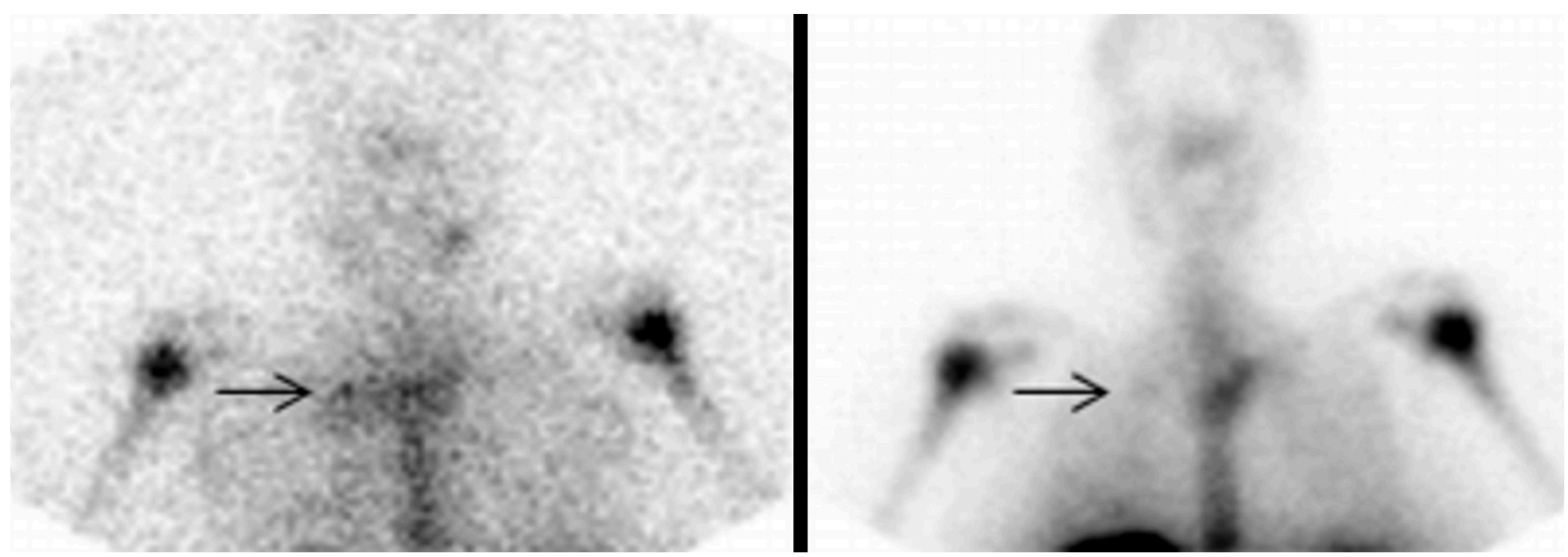

Şekil 3. Sağ sternoklavikular ekleme ait enfeksiyonun in vitro lökosit işaretli sintigrafi bulguları.

teknesyum 99-m-HMPAO'dur. Radyo-etiketleme prosedürü yaklaşık üç saat sürmektedir. Tatmin edici görüntü elde edilmesi için hastanın lökosit sayısının minimum 2000/microL olmalıdır. Genellikle nötrofiller daha fazla bağlamaktadır bu nedenle bakteriyel enfeksiyonlar gibi nötrofil aracılı enflamasyonda bu prosedür oldukça yararlıdır. Bu prosedür predominant hücresel cevabı nötrofil hücresi olmayan tüberküloz gibi hastalıklarda daha az kullanışlıdır. ${ }^{[10-13]}$ Lökosit işaretli görüntüleme, komplike osteomiyelitin tanısında tercih edilen radyonüklid prosedürüdür. Enfeksiyonun yokluğunda genellikle artmış kemik döngüsünün olduğu bölgelerde birikmese de işaretli lökositler kemik iliğinde birikebilmektedir. Gerçekte aktif kemik iliğinin hematopoetik normal dağılımı değişkendir. Orak hücreli anemi ve Gaucher hastalığı gibi sistemik hastalıklarda kemik iliği dağılımındaki değişiklikler jeneralize iken ortopedik implant uygulanan hastalarda ve nöropatik eklem tanısı olan hastalarda bu değişkenlik lokalizedir. Çocukluk çağında hematolojik olarak aktif kemik iliğinin normal dağılımı yaş gruplarına göre değişiklik göstermektedir. Sonuç olarak, işaretli lökosit sintigrafisi ile saptanan bir aktivite alanının enfeksiyonu ifade edip etmediğini veya atipik bir tutulumu olan normal bir kemik iliğinin olup olmadığını ayırt etmek mümkün olmayabilir. Bunun bir sonucu olarak da teknesyum 99-m sülfür kolloid kemik iliği görüntülemesi sıklıkla gerekmektedir. ${ }^{[14]}$ Normal kemik iliğinde hem işaretli lökositler hem de sülfür kolloidler tutulum yaparken enfeksiyonda sülfür kolloid tutulumu gerçekleşmez. ${ }^{[15]}$ Sonuç olarak lökosit işaretli/kemik iliği sintigrafisi tanıda doğruluk oranını \%90'lara taşımaktadır (Şekil 3). ${ }^{[16]}$ 


\section{In Vivo Lökosit İşaretli Sintigrafi}

İn vitro lökosit işaretli sintigrafinin birçok limitasyonu bulunduğunda peptitler ve anti granülosit antikorları dahil olmak üzere in vivo lökosit işaretleme yöntemlerinin araştırılması için büyük çaba harcanmıştır. ${ }^{[17]}$

Bir murin monoklonal IgGl antikoru olan besilesomab, granülosit ve granülosit öncü hücre membranları üzerinde çapraz reaksiyona giren antijen-95'e bağlanır. Enjeksiyondan sonraki 45 dakikada \%10 oranında nötrofillere bağlı enjeksiyon aktivitesi oluşurken, \%20 oranında kanda serbest dolaşan aktiviteye ulaşılır. Genellikle enjeksiyon sonrası 6. saatten itibaren görüntüleme çalışmalarına başlanabilmesine rağmen lezyonların saptanma olasılığı daha yüksek olduğundan genellikle önerilen 24 saat sonra yapılacak olan görüntülemelerdir. Osteomiyelit için duyarlılığı kalça için \%69 iken alt ekstremite ve ayak bileğinde \%100'e ulaşmaktadır. ${ }^{[18]}$ Bu maddenin önemli bir dezavantajı, tek enjeksiyon yapılan hastalarda \%5'ten az, tekrarlanan enjeksiyon alan hastalarda ise \%30'dan daha fazla değişen, doza bağlı insan antimurin antikoru (HAMA) cevabıdır. Sulosomab (leukoskan), lökositler üzerindeki NCA-90 antijenine bağlanan IgG1 sınıfından bir murin monoklonal antikorunun bir 50-kD'lik fragman antijen bağlayıcı (Fab) kısmıdır. Enjekte edilen 99 mTcsulesomabın yaklaşık \%3-6'sı dolaşımdaki nötrofillere bağlanırken; 24 saate kadar, yaklaşık \%35'i kemik iliğindedir. Illk araştırmalar enfeksiyonda tutulumun dolaşımdaki nötrofillere ve enfeksiyon bölgesinde mevcut olan lökositlere bağlanmayı içerdiğini gösterse de daha sonraki veriler enfeksiyonda birikimin özgül olmadığını göstermiş̧tir.

Lökositler üzerindeki bir kemokin reseptörü tip 1 ve 2'ye bağlanan kemotaktik bir sitokin olan interlökin 8, enfeksiyonda hızla birikir. Sınırlı araştırmalar bu ajanın kas-iskelet sistemi enfeksiyonunu doğru bir şekilde teşhis ettiğini göstermektedir. ${ }^{[19]}$

\section{In-Biotin}

Biyotin veya glikoz metabolizmasında önemli olan B7 vitamini bakteriyel bir büyüme faktörüdür. 111lnbiotin, yalnız ve streptavidin ile birlikte enfeksiyon tanısında kullanılmıştır. Avantajları arasında aynı gün görüntüleme yapmaya olanak vermesi ve çok az kemik iliği tutulumunun bulunmasıdır ve antibiyotik tedavisinin duyarlılığını etkilememesidir.

\section{Antibiyotik İşaretli Sintigrafi}

Radyo-etiketli antibiyotikler enfeksiyona özgü ajanlar geliştirmeye çalıştı. En kapsamlı araştırılan radyoetiketli antibiyotik 99 mTc-siprofloksasindir. Illk araştırmalar yüksek hassasiyet ve özgüllük bildirse de daha sonraki araştırmalar özgüllük hakkında ciddi sorular nedeniyle antibiyotik işaretli sintigrafiye gösterilen ilginin azalmasına neden olmuştur.

\section{Antimikrobiyal Peptid İşaretli Sintigrafi}

Birçok canlının doğal savunma sistemlerinin bir parçası olan antmikrobiyal peptidler küçük katyonik ve amfipatik moleküllerdir. Ekspresyonları sabit ya da mikrobioma temas ile indüklenir. Dolaşımda bulunan lökositler tarafından taşınabilirler. Bu peptidlerin mikroarganizmaları yok edebildiği eş zamanlı olarak memeli hücrelere zarar vermediği gözlenmiş ve bu açıdan potansiyel teröpatik ve diagnostik bir ajan olabileceği ile ilgili bazı çalışmalar yapılmıştır. Antimikrobiyal peptidler içinde üzerinde en çok çalışma yapılan peptid mürin makrofajlarda bulunan radyoaktif işaretli sentetik ubiqusidin fragmanlarıdır. ${ }^{[19-21]}$

\section{F-FDG}

18F-FDG, glikoz yoluyla hücrelere taşınır ve heksokinaz ile 18F-2'-18F-FDG-6 fosfata fosforile edilir ancak daha fazla metabolize edilmez. Lökositler tarafından alım, hücresel metabolik hıza ve glukoz taşıyıcı sayısına bağlıdır. Aktive olmuş enflamatuvar hücreler tarafından glukoz taşıyıcılarının ekspresyonunda ve miktarında artma görülür ve bu taşıyıcıların enflamasyon sırasında 18F-FDG'ye afinitesi artar 18F-FDG Pozitron Emisyon Tomografisi (PET) görece yüksek rezolüsyonlu görüntüleme olanağı sunan radyofarmasötik lokalizasyon hakkında görece kesin bilgi veren bir yöntemdir. Küçük bir molekül olan 18F-FDG perfüzyonun zayıf olduğu bölgelere hızlıca ulaşabilme özelliğine sahiptir. Enjeksiyondan sonraki bir saatte görüntüler elde edilir. Tutulum travma ya da cerrahi sonrası 3-4 ay kadar sürmektedir. Dejeneratif değişiklikler genellikle hafif tutulum yapma eğilimindedir. ${ }^{[7]}$

\section{F-FDG İşaretli Lökosit}

Radyofarmasötik olarak daha özgül PET yöntemlerinin geliştirilmesi amacıyla in vitro 18F-FDG işaretli lökosit yöntemi üzerinde çalışmalar yapılmıştır. Bu işaretlemede 18F-FDG'nin yarılanma ömrünün uzun olması nedeniyle görüntülemeyi geciktirmesi, 111 Inoxine2 göre daha düşük ve değişken işaretleme özelliği göstermesi ve 18F-FDG'nin lökositlerden hızlıca elüsyona uğraması önemli dezavantajlar olarak sayılmaktadır. ${ }^{[22]}$

\section{YUMUŞAK DOKU ENFEKSIYONLARI}

\section{Nekrotizan Fasiit}

Oldukça nadir görülen, sıklıkla grup A streptokok ve stafilokok türlerinin etken olduğu bir subkutan yumuşak doku enfeksiyonu olup deri altı yağ ve kas 
dokusunun nekrozu ile karakterizedir. ${ }^{[23]}$ Nekrotizan fasiit (NF) en sık alt ekstremitelerde görülmektedir. En hızlı yayılım gösteren yumuşak doku enfeksiyonlarından biri olup saatler içinde tüm ekstremiteyi etkileyebilir. Diyabet, kronik alkolizm, karaciğer ve böbrek yetmezliği gibi durumlarda sık görülmekle birlikte olguların yarıya yakını sağlıklı kişilerdir. ${ }^{[24]}$ Fizik muayenede beklenmedik oranda ağrı, progresif eritem ve hassasiyet ile birlikte yumuşak dokuda krepitasyon hissedilmesi ve geç dönemde doku nekrozlarının ortaya çıkması ile karakterize olup radyografilerde cilt altı dokularda hava görülmesi tipiktir. ${ }^{[2]}$ Halsizlik ve ateş tabloya eşlik etmektedir. Klinik olarak selülit ve abse gibi enfeksiyonlara benzemesi ve yaygın enfeksiyonun ciltteki bulgularının özgül olmayışı hastalık tanısını güçleştirir. ${ }^{[25]}$ Klinik bulgulara göre evrelendirildiğinde; Evre I'de (erken evre): palpasyon ile hassasiyet, deride ISı artışı, eritem ve şişlik, Evre II'de (orta): bül formasyonu ve deride fluktuasyon, Evre III'te (geç) ise: krepitasyon, deride anestezi, deride renk koyulaşması, gangrene varan doku nekrozu görülür.

\section{Gazlı Gangren}

Gazlı gangren, patojenik klostridyum türü anaerop bakterilerin toksinlerinin iskelet kaslarına invazyonu ile oluşan, yağ ve kas nekrozu ile giden, sistemik toksisite ve intravasküler hemoliz ve tromboz ile karakterize bir enfeksiyondur. ${ }^{[26]}$ Klinik olarak ciltte renk değişiklikleri ile birlikte ciddi ağrı, ödem, yüksek ateş, taşkardi, ve konfüzyon görülür. Radyografide tipik olarak yumuşak doku içinde yaygın gaz görünümü mevcuttur. Hastanın klinik bulguları toksik bir tablo ile uyumludur.

\section{Selülit}

Sıklıkla S.aureus'un etken olduğu cilt ve cilt altı dokuların enfeksiyonudur. Ciltte erken dönemde hiperaljezi, kızarıklık ve ısı artışı görülür. Lezyonun deri üzerindeki sınırları belirgin değildir. Ateş, üşüme-titreme ve bölgesel lenfadenopati sıklıkla enfeksiyona eşlik eder. Ciddi olgularda bakteriyemi ile birlikte ateş, taşikardi, konfüzyon ve hipotansiyon gelişebilir Tedavi gecikirse cilt altı dokularda fluktuasyon gösteren abseler görülebilir. ${ }^{[2,27]}$ Radyolojik olarak yumuşak dokuda ödem görülebilir. İlerlemiş enfeksiyon düşünülen hastalarda cilt altı abselerin yerleşim yerleri açısından MR görüntüleme yararlıdır.

\section{OSTEOMIYELIT}

Osteomiyelit kemik dokusunun enfeksiyonudur. Patojenik mikroorganizmalar kemiğe iki yolla ulaşır: direkt yolla (komşu enfekte doku, penetran yara, açık kırık ve cerrahi gibi) ve kan akımı yoluyla hematojen olarak.

\section{Akut Hematojen Osteomiyelit}

Primer hematojen osteomiyelit erişkinlerde nadir görülür. Sıklıkla yenidoğan ve çocukların hastalığıdır. Hematojen yayılım en fazla kemiklerin aktif büyüyen kısmı olan kemiğin metafizer bölgesinedir. Çocuklarda metafiziyel arterler büyük sinüzoidal venlerle birleşerek büyüme plağında sonlanır. Kan akımı bu bölgede yavaşlar ve bakterilerin çoğalmasına olanak sağlar. Yenidoğanlarda medüller enfeksiyon büyüme plağını kat eden kapiller damarları izleyerek eklem yüzeylerine yayılım gösterebilir. Çocuklarda ise enfeksiyon metafiz ve diyafizle sınırı kalır. Çocuklardaki akut hematojen osteomiyelitin tipik bulgusu ateş, irritabilite, letarji ve özellikle ekleme yakın ekstremite ağrısıdır. Etkilenen ekstremitede olan ağrı ekstremiteyi koruma ve kullanmama olarak karşımıza çıkabilir. Bakteriyemi esnasında klinik bulgu görülmeyebilir, ancak bakteri kemiğe yerleştikten sonra ani başlangıçı̆ı ağı ile birlikte ateş ve hassasiyet görülür. Küçük çocuklarda psödoparalizi sık görülen bir bulgudur. ${ }^{[28]}$ Akut safhada, vasküler konjesyon ve küçük damar trombozunun eşlik ettiği süpüratif enfeksiyon oluşur ve kemik nekrozu "sekestr" gelişir. Sağlam dokularda nekroz osteomiyelitin karakteristiğidir. Çocuklarda geniş sekestrlerin rezorpsiyonu ve belirgin periosteal yanıt geliştirebilme yeteneği vardır. Bu yetenek enfeksiyon çevresinde involukrum oluşmasına neden olarak çocuklarda kemik bütünlügünü korur ve patolojik kırık ile kaynamama oluşma oranını düşürür. ${ }^{[29]}$ Erişkinlerde hematojen osteomiyelit oldukça nadir görülür. Sıklıkla intravenöz ilaç kullanım öyküsü olan ya da immun yetmezliği olan hastalarda karşımıza çıkar ve travma, açık kırıklar, delici yaralanmalar sonucu gelişen direkt bulaş sonucu görülür. Erişkin osteomiyeliti sıklıkla diyafizde başlar ve tüm intramedüller kanala yayılabilir. Periost erişkinlerde kemiğe sıkı sıkıya yapıştığından kortikal perforasyonun ardından yumuşak doku abseleri görülür.

\section{Subakut Hematojen Osteomiyelit}

Hastaların başlıca yakınmaları hafif ya da orta şiddette ağrıdır. Ağrının karakteri aktiviteden bağımsız artmakta ve aspirine sıklıkla yanıt vermektedir. Bu nedenle osteid osteoma ile karışabilir. Hafif topallama ve fizik muayenede lokal ısı artışı sıklıkla gözlenir. Sınırlı enfeksiyon nedeniyle akut hematojen osteomiyelitte olduğu gibi sistemik bulgular genelde bulunmaz. Bu nedenle tanıda gecikme yaşanabilir. Beyaz küre sayımı sıklıkla normaldir, sedimentasyon hastaların sadece $\% 50$ 'sinde yüksek olarak saptanır ve kan kültürleri genelde negatiftir. ${ }^{[30,31]}$

\section{Brodie Absesi}

Genellikle genç erişkinlerde ve alt ekstremite uzun kemiklerinde oluşan subakut osteomiyelitin bir tipidir. 

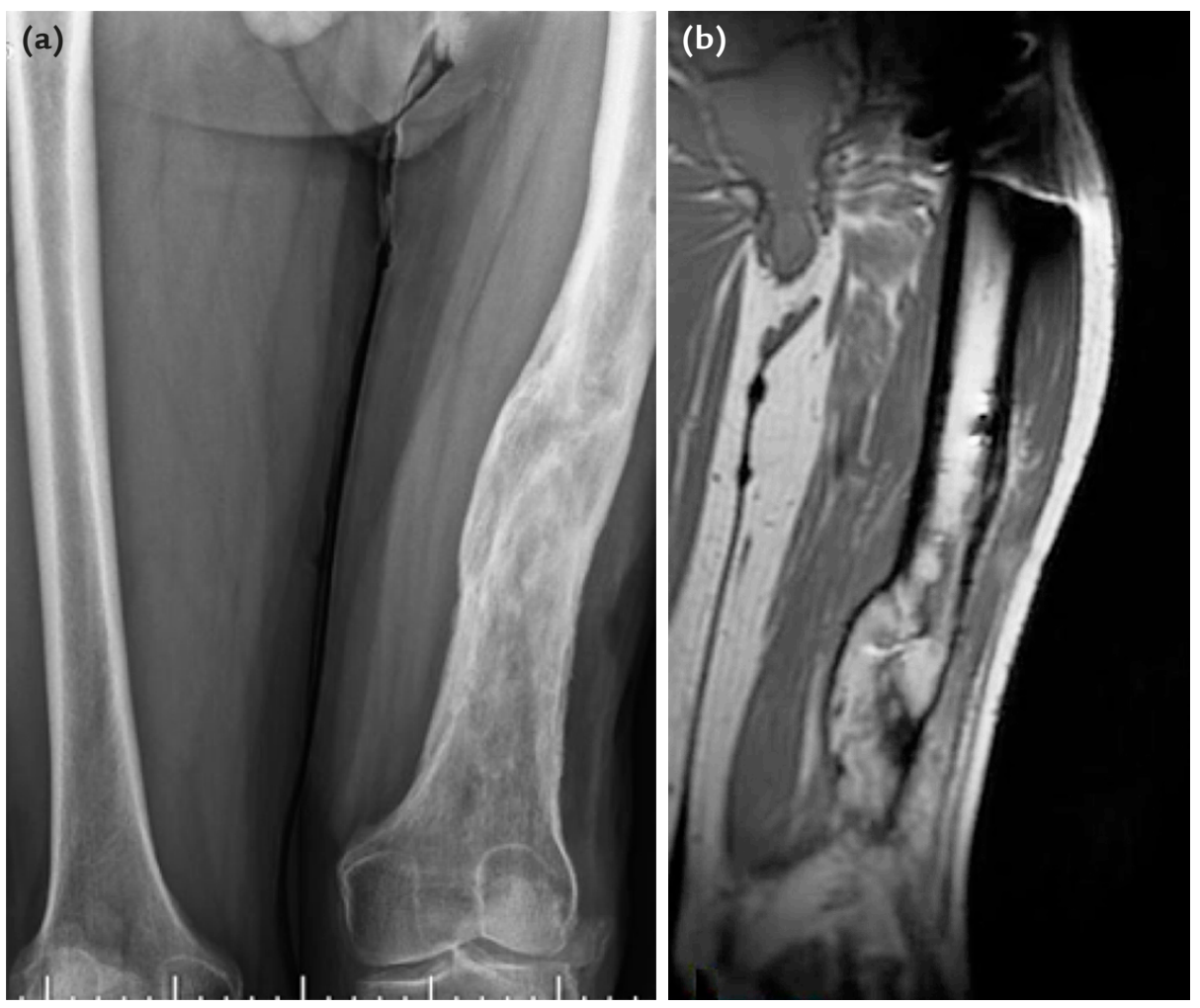

Şekil 4. a, b. Sol femur $1 / 3$ distal kronik osteomiyelit; direkt grafisi (a) ve MR görüntüsü (b).

Enfeksiyon periostun eleve olmasına neden olur. Klinik bulgu olarak uzun süre devam eden aralıklı ağrıyla birlikte, tutulum olan bölgede lokal hassasiyet görülür. ${ }^{[31]}$

\section{Garre'nin Sklerozan Osteomiyeliti (Proliferatif Periostitis)}

Çocuklarda ve gençlerde sık görülen bir osteomiyelit formudur. Klinik bulgu olarak uzun süre devam eden aralıklı ağrıyla birlikte, tutulum olan bölgede lokal hassasiyet görülür. ${ }^{[31]}$ Reaktif gelişen subperiosteal kemik oluşumu ve nonsüpüratif ossifiye periostitis ile karakterizedir. Soğan kabuğu tarzında periost reaksiyonu görülür.

\section{Kronik Osteomiyelit}

Hastalar genellikle ağrı ve etkilenen ekstremitede pürülan akıntı ile başvururlar. Ateş sıklıkla olmaz, ya da subfebrildir. ${ }^{[32]}$

Osteomiyelitin radyolojik bulguları genellikle enfeksiyonun başlamasını takiben ikinci haftada ortaya çıkar. En erken radyolojik değişiklikler yumuşak dokunun şişlik ve ödemi, periostal kalınlaşma ve fokal osteopenidir. Radyografilerde litik değişikliklerin gözlenebilmesi için kemik matriksinde \%50-75 arası yıkım olması gerekir.
Sekestr ve involukrum gibi hastalığa özgün değişiklikler ise sıklıkla subakut ve kronik dönemlerde karşımıza çıkar. Kemik sintigrafisi, tanıda şüphe olduğunda veya hastalığın yaygınlığının değerlendirilmesinde kullanılabilir. Osteomiyelit için duyarlılığı yüksek ancak özgüllüğü düşüktür. BT'de en erken bulgu artmış kemik iliği yoğunluğudur. BT nekrotik kemiğin ve çevre yumuşak dokulardaki tutulumun değerlendirilmesinde oldukça yararlıdır. Osteomiyelitin yaygınlığı, yumuşak dokunun değerlendirilmesi, fistüllerin izlediği yollar en iyi şekilde MR ile değerlendirilir (Şekil 4). Akut osteomiyelitin MR görüntülerdeki en önemli bulgusu T1 ağılıklı görüntülerde anormal düşük sinyalli kemik iliği iken T2 ağırlıklı görüntülerde artmış kemik iliği sinyal intensitesidir. ${ }^{[33]}$

\section{SEPTIK ARTRIT}

Septik artrit, eklem boşluğunun, sinoviyal sıvının, sinoviyal zarın ve eklem kıkırdağının bakteriel, viral ya da fungal mikroorganizmalara bağlı oluşan enfeksiyonudur. Septik artrit sıklıkla tek eklem tutulumlu olup en sık diz, kalça, ayak bileği gibi yük taşıyan eklemler etkilenir. \%50'sinde diz eklemi tutulumu gözlenir. Omuz, dirsek, sternoklaviküler eklem, sakroiliak eklem ve el, ayak küçük eklemleri de tutulum gözlenebilen 
diğer eklemlerdir. ${ }^{[2]}$ Klinik bulgu ve semptom olarak ağrı, ateş, etkilenen eklem üzerine yük vermede zorluk, eklem hareket açıklığında kısıtılık, etkilenen eklemde ısı artışı, effüzyon ve kızarıklık görülebilir. Romatoid artritin akut alevlenmesi de benzer tablo ile karşımıza çıkabilir. Multipl eklem tutulumu ile ayrım sağlanabilir. Ayrıca kalça ve omuz eklemlerindeki effüzyonların varlığı genellikle diz eklemi kadar kolay fark edilmez ve tanıda gecikmelere neden olabilir. Küçük çocuk ve bebeklerde septik tablo daha ağırdır ve psödoparalizi olabilir. ${ }^{[34]}$ Dolayısıyla özellikle küçük çocuklarda yüksek ateş ve huzursuzluk varlığında mutlaka eklem muayenesi yapılmalıdır. ${ }^{[35]}$

Radyolojik incelemeler; septik artrit tanısının desteklenmesi veya tanıda şüphe olması durumunda yardımcı tanısal yöntem amacıyla kullanılabilir. Asla kesin tanısal yöntem olarak kullanılamaz. Hastalığın ilk 7-10 günü içerisinde radyografik bulgu olarak sadece eklem aralığında artış ve effüzyon gözlenir. US kalça gibi derin eklemlerdeki effüzyonları belirlemekte daha yararlı olabilir. BT de erken evrede sınırlı yarara sahiptir. Kalça, sakroiliak ve sternoklaviküler eklemler gibi derin yerleşimli eklemlerde effüzyonları ve eklem çevresi yumuşak doku şişliklerini gösterir. MR görüntüleme ise kas-iskelet sistemi enfeksiyonunun tanısı ve yaygınlığının gösterilmesinde erken dönemdeki en yararlı incelemedir. Septik artrit tanısında muayene ve diğer laboratuvar testlerinin tanıda ön planda olması nedeniyle kullanımı sınırlıdır.

\section{DIYABETIK AYAK ENFEKSIYONLARI}

Diabetus mellitus (DM) hastalarında gelişen periferik nöropati ve vasküler hastalıklar, diyabetik ayak ülserlerinden sorumlu olan en önemli mekanizmadır. ${ }^{[36,37]}$ Nöropatiyle beraber propriyoseptif duyuların kaybına bağlı olarak gelişen Charcot eklemi ayak plantar yüzde basınç artışına ve ağrı duyusu kaybıyla birlikte sonuçta ayakta ülserasyonlara yol açmaktadır. ${ }^{[37]} \mathrm{Bu}$ hastalardaki sempatik otonomik nöropati alt ekstremitede terlemeyi azaltır ve kuru, çatlak bir cilt yapısına neden olur. Oluşan çatlaklardan enfeksiyöz ajanlar penetre olarak enfekte ülser oluşumuna neden olabilirler. Motor nöropatide en sık etkilenen sinir ana peroneal sinirdir. Hastalarda tibialis anterior kasında motor kayba bağlı düşük ayak ve ayak intrinsik kasların etkilenmesine bağlı pençe parmak görülür. ${ }^{[38]}$

Direkt grafiler diyabetik ayak lezyonlarında, kemik yapıların dansitesini, korteks ve medulla ilişkisini, periost reaksiyonunu, yumuşak dokuya ait hava ve kalsifikasyon gibi lezyonların değerlendirilmesini sağlar (Şekil 5). Direkt radyografiler diyabetik hastalarda oldukça sık görülen ancak genellikle farkına

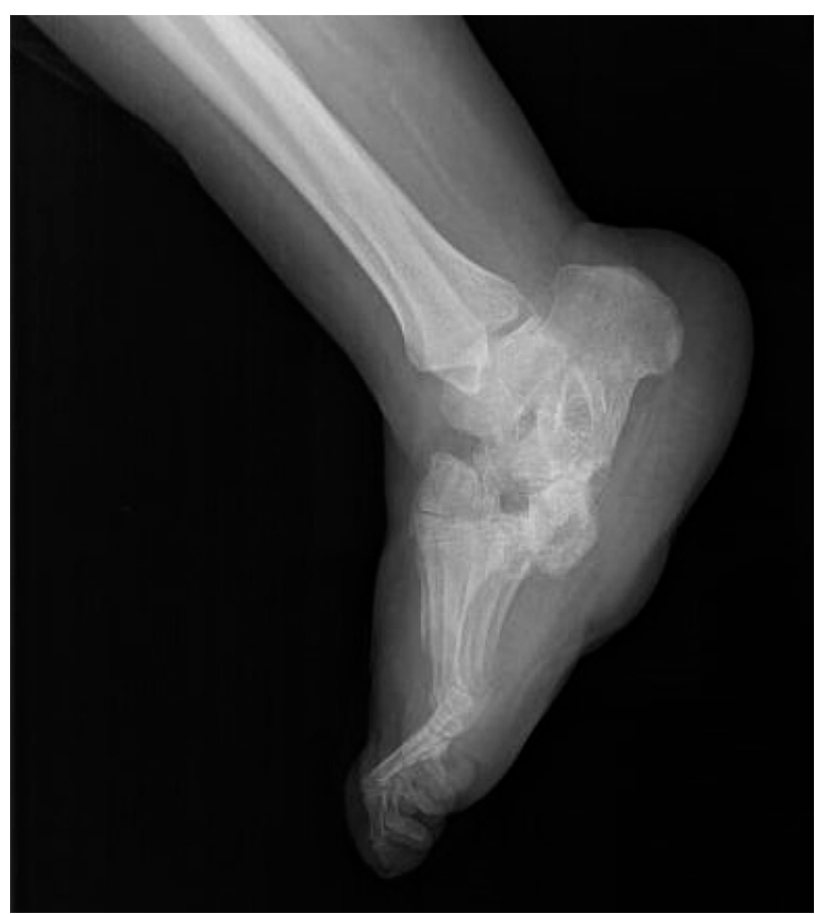

Şekil 5. Diyabetik ayak enfeksiyonu direkt grafisi.

varılamayan, eski travmatik fraktürler ile yabancı cisimlerin saptanmasını da sağlar. Direkt radyografilerde kemikte rezorpsiyon ("kalem ucu" tarzında incelen metatars) varlı̆̆ı noniskemik, yani nöropatik kemik patolojisi olarak değerlendirilir.

Renkli Doppler US, vasküler sistemin temel noninvaziv görüntüleme yöntemidir. Diyabetik hastalarda damar kalsifikasyonları daha belirgin olduğundan anjiyografi ile karşılaştırıldığında, renkli Doppler incelemenin duyarlılığı ve özgüllüğü oldukça yüksektir. Sık olmasa da anjiyografi ile tam tıkanma saptanan distal arterlerde, renkli Doppler US ile çok düşük akımlar saptanabilmektedir. ${ }^{[39]}$ BT ile ayak gibi komplike eklemlere sahip bölgelerde şüpheli subluksasyonlar saptanabilir. MR ile diyabetik ayakta saptanan patolojilerde duyarlıık oranı $\% 90$ ve özgüllük oranı \%83'tür.

\section{ATIPIK ENFEKSIYONLAR}

\section{Tüberküloz}

Mycobacterium tuberculosis ve bovis'in inhalasyonu ya da sindirim sistemi ile bulaşı sonrası lenfatik ve komşuluk yoluyla yayılır. Tutulan eklem fonksiyonlarında kayıp, 15 günden uzun süren öksürük, ateş, 
gece terlemesi ve halsizlik gözlenir. Olguların yaklaşık \%1-8'inde kemik tutulumu görülür. ${ }^{[40]}$ Kemik tutulumu olarak en sık omurga ve özellikle torasik vertebra tutulumuna rastlanır. Hastaların \%80'inde disk tutulumu mevcut olup sıklıkla vertebra gövde anterioru etkilenir. ${ }^{[31]}$ Radyolojik olarak eklem çevresi erozyonları çoğu zaman litik görünümdedir. En fazla anterior vertebra tutulumu görülür. İntervertebral disk aralığı göreceli olarak korunmuştur. Sonraki evrelerde Pott hastalığının karakteristik bulgusu anterior kamalaşma ile kamburlaşma gözlenir. Tüm vücut kemik sintigrafisi \%88-96 oranında duyarlıdır (sensitiftir). BT paraspinal abselerin gelişimini ve spinal kanal tutulumunu göstermede radyografiye göre üstündür. Kontrastlı tomografi kesitlerinde, paravertebral abseler, periferik kontrastlanma gösteren santrali hipodens alanlar şeklinde gözlenir. MR görüntülemede, T1 ağırlıklı görüntülerde azalmış, T2 ağırlıklı görüntülerde ise artmış sinyal yoğunluğu, tüberküloz spondilitin tipik bulgusudur.

\section{Bruselloz}

Brucella melitensis, Brucella abortus, Brucella suis ve Brucella canis brusellozdan sorumlu gram negatif zoonozlardır. Bu etkenlerin vücuda girişinden semptomların başlamasına kadar geçen süre ortalama 1-3 haftadır. Kadınlarda erkeklere oranla daha sık görülür. Brusellozda klinik bulgular genellikle lenfadenopati, hepatomegali, artralji, artrit ve pansitopenidir. Ateş ve osteoartiküler bulgular daha ön plandadır. Brusellozlu hastalardaki kas-iskelet sistem tutulumu yaklaşık \%2-53 oranında olup, kas-iskelet sistem bulguları ise sırasıyla sakroileit, artrit-artralji, spondilit, osteomiyelit ve bursit olarak bildirilmiştir. ${ }^{[41,42]}$ En sık rastlanan bruselloza bağlı kas-iskelet sistemi tutulumu sakroileit olup, çoğunlukla tek taraflıdır. Spinal tutulum sıklıkla, "papağan gagası" görünümüne yol açar. Üst son plakları etkiler ve frank osteomiyelitine ilerleyebilir. En sık lomber vertebralar olmak üzere sırasıyla, servikal ve torakal vertebralarda tutulum görülür. ${ }^{[43]}$ Yine radyolojik olarak eklem aralığı düzensizleşebilir; bu duruma eklem koksaljisi adı verilir. Vertebra body köşesinde yuvarlaklaşma veya basamak deformitesi ile birlikte olan üst proksimal erozyonu "Pedro Pons" bulgusu olarak tanımlanır ve brusella spondilitinin karakteristik radyolojik bulgusudur. Bu hastalarda spinöz prosesler de tutulabilir ve epidural abse oluşabilir. Oluşan epidural abse, fitıklaşmış diske benzer bir tablo ortaya çıkarsa da hastalıkta, çoğunlukla intervertebral disk korunmuştur. Tüm vücut kemik sintigrafisinin brusellozun akut döneminde $\% 60$, kronik döneminde ise $\% 40$ oranında tanı değeri vardır. Bu nedenle özellikle akut dönemde yararlı bir yöntemdir. ${ }^{[44]}$

\section{Sifiliz}

Kas-iskelet sistem tutulumu hastalığın herhangi bir evresinde ve herhangi bir yaşta oluşabilir. Konjenital sifilizde tibia proksimalinde korteks kalınlaşması görülebilir (kılıç kını tibia). Erken dönemde belirti vermeyen el, ayak, önkol, klavikula, tibia tutulumu olabilir. Hastalık spinal arka köklerin tutulumu sonucu arka kordonların dejenerasyonuna bağlı olarak tabes dorsalise yol açabilir. Hastalarda pozisyon ve vibrasyon duyuları özellikle bacaklarda ileri derecede bozulmuştur. Göz kontrolu ortadan kalkmıştır. Hastalar gözlerini kapattıkları zaman dengelerini kaybedip ayakta duramazlar (Romberg belirtisi). Hasta karanlıkta yürümekte güçlük çeker. Şiddetli radiküler ağrılar görülebilir. Patella ve aşil refleksleri alınmaz. ${ }^{[45,46]}$

\section{Fungal Enfeksiyonlar}

Sıklıkla yavaş gelişir ve tanı ve tedavilerinde gecikmeler olabilir.

\section{Koksidioidomikozis}

Coccidioides immitis artrosporlarının inhalasyonu ile olur. Yaklaşık \%20'sinde kemik ve eklemler etkilenir. Çoğunlukla diz gibi, büyük ve yük taşıyan eklemler etkilenir. Tedavi edilmeyen enfeksiyon, eklem çevresindeki yapılara infiltrasyon, kemik invazyonu ve sinus traktı oluşumu ile beraber pannus formasyonu ile sonuçlanabilir. Kemikte granülomatöz lezyonlar hastaların sadece \%15'inde görülür. Radyolojik bulgu olarak kistler, kıkırdak erozyonu ve litik lezyonlar hastalığın ileri evrelerinde görülür.

\section{Blastomikozis}

Blastomyces dermatitis sporlarının inhalasyonu sonucu oluşur. Kemik tutulumu, primer blastomikozisin üçüncü en sık formudur. Kemik bulguları blastomikozise özgü değildir ve diğer osteomiyelit formları ile benzerlik gösterir. En sık etkilenen kemikler vertebra, pelvis, sakrum, kafatası, yüz ve kostalardır. Enfeksiyon uzun kemiklerde epifizde lokalize kalma eğilimindedir.

\section{Histoplazmozis}

Histoplasma capsulatum sporlarının inhalasyonu yoluyla oluşur. Artrit, dissemine hastalığın bir parçası olarak veya soliter bir monoartrit olarak görülebilir. Kemik ve eklem tutulumlarında radyografiler normal olabilir veya eklem yüzeyinde atrofi ile çevre kemik dokularda sekonder değişiklikler görülebilir.

\section{Kriptokokkozis}

Cryptococcus neoformans bir maya mantarıdır. İmmunkompetan bireylerde çoğunlukla, asemptomatik pulmoner hastalık yaparken, immunosupresif 
hastalarda genellikle, akciğer tutulumunun ön planda olduğu, yaşamı tehdit eden, dissemine enfeksiyona neden olur. İzole kemik lezyonları hastaların yaklaşık \%10'unda bildirilmektedir. ${ }^{[4]}$ Kemik lezyonları, primer kemik neoplazmlarını veya diğer fungal kemik lezyonlarını taklit eder. Vertebra ve uzun kemiklerin yanı sıra yassı kemiklerde de tutulum gözlenebilir.

\section{KAYNAKLAR}

1. Nair SP, Meghji S, Wilson M, Reddi K, White P, Henderson B. Bacterially induced bone destruction: mechanisms and misconceptions. Infect Immun 1996;64(7):2371-80. Crossref

2. Deveci MA, Esen E, Yetkin H. Spesifik olmayan kas-iskelet sistemi enfeksiyonları. TOTBID Derg 2011;10(4):276-84. http://totbid.org.tr/files/10-4/02_2011_4_MehmetAliDeveci. pdf

3. Palestro CJ, Love C, Miller TT. Imaging of Musculoskeletal Infections. Best Pract Res Clin Rheumatol 2006;20(6):1197218. Crossref

4. Palestro CJ. Musculoskeletal infection. In: Freeman LM, editor. Nuclear Medicine Annual 1994. Philadelphia: Lippincott Williams \& Wilkins; 1994. p.91-119.

5. Miller TT, Randolph DA Jr, Staron RB, Feldman F, Cushin S. Fat-suppressed MRI of musculoskeletal infection: fast T2 weighted techniques versus gadolinium-enhanced T1weighted images. Skeletal Radiol 1997;26(11):654-8. Crossref

6. Chao HC, Lin SJ, Huang YC, Lin TY. Color Doppler ultrasonographic evaluation of osteomyelitis in children. J Ultrasound Med 1999;18(11):729-34. Crossref

7. Palestro CJ. Radionuclide imaging of osteomyelitis. Semin Nucl Med 2015;45(1):32-46. Crossref

8. Palestro CJ, Love C, Bhargava KK. Labeled leukocyte imaging: current status and future directions. Q J Nucl Med Mol Imaging 2009;53(1):105-23. https://www.minervamedica. it/en/journals/nuclear-med-molecular-imaging/article. php?cod=R39Y2009N01A0105

9. Love C, Palestro CJ. Radionuclide imaging of infection. J Nucl Med Technol 2004;32(2):47-57. http://tech.snmjournals. org/content/32/2/47.long

10. Fineman D, Palestro CJ, Kim CK, Needle LB, Vallabhajosula $\mathrm{S}$, Solomon RW, Goldsmith SJ. Detection of abnormalities in febrile AIDS patients with In-111-labeled leukocyte and Ga67 scintigraphy. Radiology 1989;170(3):677-80. Crossref

11. Palestro CJ, Swyer AJ, Kim CK, Goldsmith SJ. Tuberculous lymphadenitis: In-111 leukocyte and Ga-67 imaging. Clin Nucl Med 1991;16(11):857-8. Crossref

12. Palestro CJ, Schultz BL, Horowitz M, Swyer AJ. Indium-111 leukocyte and gallium-67 imaging in acute sarcoidosis: Report of two patients. J Nucl Med 1992;33(11):2027-9. http://jnm.snmjournals.org/content/33/11/2027.long

13. Palestro CJ, Love C, Tronco GG, Tomas MB, RiniJN. Combined labeled leukocyte and technetium-99m sulfur colloid marrow imaging for diagnosing musculoskeletal infection: principles, technique, interpretation, indications and limitations. RadioGraphics 2006;26(3):859-70. Crossref

14. Feigin DS, Strauss HW, James AE. The bone marrow scan in experimental osteomyelitis. Skeletal Radiol 1976;1(2):103-8. Crossref
15. Love C, Marwin SE, Tomas MB, Krauss ES, Tronco GG, Bhargava KK, Nichols KJ, Palestro CJ. Diagnosing infection in the failed joint replacement: A comparison of coincidence detection fluorine-18 FDG and indium-111-labeled leukocyte/technetium-99m-sulfur colloid marrow imaging. J Nucl Med 2004;45(11):1864-71. http://jnm.snmjournals. org/content/45/11/1864.long

16. Love C, Palestro CJ. 99mTc-fanolesomab Palatin Technologies. Idrugs 2003;6(11):1079-85. https://pubmed. ncbi.nlm.nih.gov/14600841/

17. Weiner RE, Thakur ML. Imaging infection/inflammations. Pathophysiologic Basis and Radiopharmaceuticals. Q J Nucl Med 1999;43(1):2-8. https://pubmed.ncbi.nlm.nih. gov/10230276/

18. Palestro CJ, Glaudemans AWJM, Dierckx RAJO. Multiagent imaging of inflammation and infection with radionuclides. Clin Transl Imaging 2013;1(6):385-96. Crossref

19. Wang G. Human antimicrobial peptides and proteins. Pharmaceuticals (Basel) 2014;7(5):545-94. Crossref

20. Hiemstra PS, van den Barselaar MT, Roest M, Nibbering PH, van Furth R. Ubiquicidin, a novel murine microbicidal protein present in the cytosolic fraction of macrophages. Leukoc Biol 1999;66(3):423-8. Crossref

21. Rutenberg TF, Baruch $\mathrm{Y}$, Ohana $\mathrm{N}$, Bernstine $\mathrm{H}$, Amitai A, Cohen N, Domachevsky L, Shemesh S. The Role of 18F-Fluorodeoxyglucose Positron-Emission Tomography/Computed Tomography in the Diagnosis of Postoperative Hardware-Related Spinal Infections IMAJ 2019;21:532-7. https://www.ima.org.il/FilesUploadPublic/ IMAJ/0/378/189320.pdf

22. Fontes RA Jr, Ogilvie CM, Miclau T. Necrotizing soft-tissue infections. J Am Acad Orthop Surg 2000;8(3):151-8. Crossref

23. Pasternack MS, Swartz MN. Cellulitis, necrotizing fasciitis, and subcutaneous tissue infections. In: Mandell GL, Bennet JE, Dolin R, editors. Principles and Practice of Infectious Diseases. Philadelphia: Churchill Livingstone; 2010. p.1289-312.

24. Bozkurt M, Zor F, Külahçı Y, Benlier E. Önkolda nekrotizan fasiit: Olgu sunumu ve literatür taraması. Cerrahpaşa Tıp Derg 2006;37:17-9.

25. Paksu MŞ, Kalaycı AG, Okur EG, Öztürk F. Nekrotizan fasiit: Nadir bir olgu. Ondokuz Mayıs Univ Tıp Derg 2006;23(3):101-5. https://dergipark.org.tr/tr/download/ article-file/188869

26. Garcia-Suarez J, de Miguel D, Krsnik I, Barr-Ali M, Hernanz $\mathrm{N}$, Burgaleta C. Spontaneous gas gangrene in malignant lymphoma: an underreported complication? Am J Hematol 2002;70(2);145-8. Crossref

27. Chambers HF, Moellering RC Jr, Kamitsuka P. Clinical Decisions. Management of skin and soft-tissue infection. $\mathrm{N}$ Engl J Med 2008;359(10):1063-7. Crossref

28. Karwowska A, Davies HD, Jadavji T. Epidemiology and outcome of osteomyelitis in the era of sequential intravenous oral therapy. Pediatr Infect Dis J 1998;17(11):1021-6. Crossref

29. Tröbs R, Möritz R, Bühligen U, Bennek J, Handrick W, Hörmann D, Meier T. Changing pattern of osteomyelitis in infants and children. Pediatr Surg Int 1999;15(5-6):363-72. Crossref

30. Hayes CS, Heinrich SD, Craver R, MacEwen GD. Subacute osteomyelitis. Orthopedics 1990;13(3):363-6. https:// pubmed.ncbi.nlm.nih.gov/2179915/ 
31. Şahin AA, Boz M. Kas-İskelet Sistemi Enfeksiyonları ve Enfekte Hasta Yönetimi. Ankara: Derman Tıbbi Yayıncılık; 2015. p.593-634. http://www.jcam.com.tr/files/KATD-3585.pdf

32. Lazzarini L, Mader JT, Calhoun JH. Osteomyelitis in long bones. J Bone Joint Surg 2004;86-A(10):2305-18. Crossref

33. Ma LD, Frassica FJ, Bluemke DA, Fishman EK. CT and MRI evaluation of musculoskeletal infection. Crit Rev Diagn Imaging 1997;38(6):535-68. https://pubmed.ncbi.nlm.nih. gov/9442978/

34. Green EN. Bone and joint infections in children. In: Weinstein SL, Buckwalter JA, editors. Turek's Orthopaedics -Principles and Their Application, 5th ed. Philadelphia: Lippincott Company; 1994. p.127-50.

35. Dlabach JA, Park AL. Infectious arthritis. In: Canale ST, Beaty $\mathrm{JH}$, editors. Campbell's Operative Orthopaedics, 11th ed. Philadelphia: Mosby Elsevier; 2008. p.723-50.

36. Işık C, Sarman H, Şahin AA, Karğı E, Sarman Z, Erkuran MK, Boyraz i, Koç B. Diyabetes mellitüs ve periferik organ tutulumu: Güncel tedavi seçenekleri. J Clin Exp Invest 2014;5(2):329-35. Crossref

37. Gupta SK, Singh SK. Diabetic foot: A continuing challenge. Adv Exp Med Biol 2012;771:123-38. https://pubmed.ncbi. nlm.nih.gov/23393676/

38. Woo KY, Santos V, Gamba M. Understanding diabetic foot ulcers. Nursing 2013;43(10):36-42. Crossref

39. Cossman DV, Ellison JE, Wagner WH, Carroll RM, Treiman RL, Foran RF, Levin PM, Cohen JL. Comparison of contrast arteriography to arterial mapping with color-flow duplex imaging in the lower extremities. J Vasc Surg 1989;10(5):5228. Crossref
40. Iseman MD. A Clinician's Guide to Tuberculosis. Philadelphia, PA: Lippincott, Williams \& Wilkins; 2000. p.129-44.

41. Louie JS, Bocanegra TS. Mycobacterial, Brucella, fungal and parasitic arthritides. In: Hochberg MC, Silman AJ, Smolen JS, Weinblatt ME, Weisman MH, editors. Osteoarticular Brucellosis. Rheumatology, 3rd ed. Edinburgh: Mosby; 2003. p.1081-2.

42. Şendur ÖF, Turan Y. Bruselloz Hastalarında Kas-i̇skelet Sistemi Tutulumu. Nobel Med 2007;3(3):16-9. https://www. nobelmedicus.com/Content/1/9/16-19.pdf

43. Aydin M, Yapar AF, Savas L, Reyhan M, Pourbagher A, Turunc TY, Demiroglu YZ, Yologlu NA, Aktas A. Scintigraphic findings in osteoarticular brucellosis. Nucl Med Commun 2005;26(7):639-47. Crossref

44. Guven GS, Cakir B, Oz G, Tanrıver MD, Turkmen E, Sozen $\mathrm{T}$. Could remembering the prozone phenomenon shorten our diagnostic journey in brucellosis? A case of Brucella spondylodiscitis. Rheumatol Int 2006;26(10):933-5. Crossref

45. Shah BB, Lang AE. Acquired neurosyphilis presenting as movement disorders. Mov Disord 2012;27(6):690-5. Crossref

46. Davis LE, Schmitt JW. Clinical significance of cerebrospinal fluid tests for neurosyphilis. Ann Neurol 1989;25(1):50-5. Crossref

47. Bayer AS, Choi C, Tillman DB, Guze LB. Fungal arthritis. V. Cryptococcal and histoplasmal arthritis. Semin Arthritis Rheum 1980;9(3):218-27. Crossref 